\title{
iPS cells generation: an overview of techniques and methods
}

\author{
Telpalo-Carpio SA ${ }^{1}$, Aguilar-Yañez $\mathrm{JM}^{1}$, Gonzalez-Garza $\mathrm{MT}^{2}$, Cruz-Vega DE ${ }^{2}$, Moreno-Cuevas $\mathrm{JE}^{2}$
}

Cell therapy is one of the principal and most promising research areas of regenerative medicine. Nevertheless different ethical problems related with the use of embryonic stem cells arise from this technology. Thus the search for a feasible way of stem cells generation is in current investigation. Induced pluripotent stem (iPS) cell is one of the most encouraging emerging technologies that represent a solution to this problem. Different methods that change cell protein and gene profiles, as well as its morphology and function, driving the cell to the stem cell state have been developed. These include nuclear transfer, the usage of cell extracts and synthetic molecules, the forced expression of defined genes and cytoplasmatic level modifications. Even though favorable results have been achieved, there are still issues that require special attention. Advances with non-integration methods are now available but dedifferentiation efficiency is yet an area of opportunity. The main objective of this review is to show the most important techniques, their advantages and opportunity areas in the field of iPS cell generation.

Key Words: Induced pluripotent stem cells, iPS, dedifferentiation methods

\section{Introduction}

Totipotency is a term used to define the capacity of a portion of an organism to generate or regenerate an entire new one $^{[1]}$. Totipotent cells have the ability to develop into any of the three germinal layers (endoderm, mesoderm and ectoderm) and into cells of the two placental layers. Due to the fact that in higher mammals, totipotency has been proven difficult to achieve ${ }^{[2]}$, dediferentiations towards multipotency and pluripotency are being explored, driving the major scientific efforts to the production of these types of stem cells. Multipotent stem cells are those capable of differentiation into multiple but limited lineages. Pluripotent stem cells might be considered as the genomic state from which other patterns of the genome activity arise later in development, being able to derive into any of the three layers of the three germ lines ${ }^{[1,3]}$

Stem cells are responsible for tissue homeostasis maintenance, as they substitute injured and/or aged cells with new ones ${ }^{[4]}$.

During the last years, pluripotent embryonic stem (ES) cells have been derived from the inner cell mass of human embryos ${ }^{[2]}$; nonetheless for research purposes this method to obtain raw-material is limited and not widely socially or ethically accepted. Because of this, the necessity of having a different source of stem cells which can be later applied in therapeutic and diagnostic studies generated a broad new research line: induction of pluripotency in differentiated cells. This means going back in the development timeline to obtain stem cells from those that have been fully or partially differentiated.
Promising results have been obtained. Induced pluripotent stem (iPS) cells have been derived from murine and human somatic cells. Although they develop correctly in vitro, in vivo experiments do not always give the expected results, as iPS engraft in some but not all areas of the target organ, where they proliferate and differentiate ${ }^{[1]}$. Besides, due to their ability to derive in any germline cell, they are also associated with high rates of teratomas in recipients.

The successful development of a safe efficient procedure for cell dedifferentiation represents an alternative that can be the difference between rejected or insufficient transplants and improved life expectancies for thousands of people around the world with better and faster drug research and development ${ }^{[5,6]}$.

The purpose of this review is to give a general scenario of the state of the art in iPS cells generation, showing the most important and promising emerging dedifferentiation technologies of various research groups all over the world.

\section{Pluripotency induction methods}

Experimental protocols on this subject have been developed at high rates for around ten years, although Evans and Kauffman started embryonic stem cells generation studies almost thirty years ago ${ }^{[4]}$. Diverse mouse, rat and human cell lines are used to analyze genes implicated in the differentiation process and the pluripotent state retention.

There is little known about reprogramming mechanisms, but it is certain that chromatin modification is a key step in the process. 
Once dedifferentiation is achieved, LIF, Wnt and BMP pathways are involved in maintaining ES cells in the selfrenewal state ${ }^{[7]}$.

Dedifferentiation can be evaluated at different levels. Cell gene expression profile is reversed, thus developmentrelated gene activity is turned off as undifferentiation-related genes are activated. At the protein level, upregulation of progenitor cell-related proteins can be observed and differentiated cell-related proteins are downregulated. Talking about morphology, dedifferentiated cells are smaller, have a higher karyoplasmic ratio and fewer organelles than differentiated ones. At the functional level, they have the ability to become a broader variety of cell types than those differentiated ${ }^{[8]}$.

Nonetheless, another problem arises when the reprogramming method has to be chosen. There are multiple ways to reverse differentiation, but none of them have been able to reverse the process without the use of viral vectors, cell fusion or with guaranteed in vivo safety.

\subsection{Dedifferentiation methods}

Different methods have been explored to accomplish the reprogramming objective (Table I), as well as experimentation with different cell lines, in order to find which ones have greater dedifferentiation efficiencies.

\subsubsection{Nuclear transfer}

Somatic cell nuclear transfer (SCNT) is a process by which a somatic cell nucleus is fused with a mature enucleated oocyte. An incomplete epigenetic remodeling of the somatic nucleus is given, driving the cell to a totipotent state without the reprogramming that normally happens during development ${ }^{[9,10]}$. The ability of the oocyte to reprogram is influenced by the donor cell type. Nuclei of cells that are relatively less differentiated support better full-term development, compared with those of fully differentiated cells. Epigenetic reprogramming during cloning is a haphazard and stochastic process; therefore many defects may appear when the process is not fully successful. Among these defects are errors in $X$ chromosome activation, imprinting, DNA methylation in general and of specific gene and repeat sequences, widespread alteration in gene expression, histone acetylation and methylation ${ }^{[10]}$.

Only nuclei that have undergone appropriate epigenetic reprogramming are capable of generating human embryonic stem (hES) cells from SCNT embryos ${ }^{[9]}$.

\subsubsection{Cell extracts}

This technique involves the use of an extract from another differentiated cell type or of undifferentiated, pluripotent ES or ES cells ${ }^{[11]}$. Its results are attractive as it might allow purification of protein complexes with reprogramming capability ${ }^{[12]}$.

Epithelial NIH3T3 and 293T cells have undergone dedifferentiation using human teratocarcinoma (NCCIT) cells extract, in which genes characteristic of multilineage differentiation potential are upregulated ${ }^{[13]}$.

Experiments, done with Xenopus egg extracts, have demonstrated that efficient chromatin remodeling of differentiated nuclei depends on their exposure to mitotic egg extracts facilitating embryonic DNA replication ${ }^{[12,14]}$.

Bru et al. ${ }^{[15]}$ inducted Oct4, Sox2, Klf4 and cMyc (OSKM) genes after exposing fibroblasts to ES cells extracts, otherwise cells were permeabilised with Xenopus egg extracts, being unable to repeat Hansis et al. ${ }^{[14]}$ results.

Freberg et al. ${ }^{[11]}$ were able to reprogram DNA methylations and histone modifications on regulatory regions of Oct 4 and Nanog genes on human embryonic kidney cells via exposure to embryonic carcinoma cells extracts.

Fibroblasts exposed to mouse embryonic stem cells (MESC) extracts demonstrated that a transient induction of Oct4 triggers its long-term expression causing DNA demethylation and stemness state ${ }^{[13]}$

One of the disadvantages of this method is its difficulty to conclude, in short term, if the protein expression profile of the target cell corresponds to its own protein production due to reactivation of stem state genes or if it is consequence of the transient expression of the ones contained in the extracts in which the cells are growing ${ }^{[11]}$.

On the other hand these cells were not proved to be fully pluripotent in terms of the transcriptional state and differentiation capacity into the three germ layers. Thus Cho et al. ${ }^{[16]}$ worked on treating primary somatic cells with an ES cell-derived proteins extract, being able to generate proteiniPS cells that resemble ES cells characteristics, including in vitro functionality and in vivo developmental potentials.

\subsubsection{Forced expression of defined genes}

Transfection of embryonic and somatic cells with Oct4, Sox2, KIf4 and cMyc (OSKM) genes is capable of inducing stem cell-like characteristics expression ${ }^{[9,17]}$. Different combinations that include also Nanog homebox ${ }^{[3,9,18]}$, Stat3 ${ }^{[3]}$, LIN28 [18, 19], Esrrb ${ }^{[20]}$, SV40LT ${ }^{[21-23]}$, UTF-1 ${ }^{[24,25]}$, p53 siRNA ${ }^{[24]}$, hTERT ${ }^{[23]}$, Wnt3a ${ }^{[26]}$ and Nr5a2 ${ }^{[27]}$ had been used as well, some of which have proved to increase reprogramming efficiency or are able to substitute one of the OSKM genes. Integrative and non-integrative methods have been explored.

\section{Integrative methods}

The main problem of this approach is the use of retrovirus, lentivirus or adenovirus to deliver the differentiation genes. The first ones can cause the reactivation of cancer genes once they are fully integrated to the cell genome ${ }^{[28,29]}$. On the other hand, adenoviral vectors can integrate into the genome of host cells at extremely low frequencies, a probable cause of the low efficiency rates reported so far ${ }^{[30,}$ 31]. Constitutive and inducible promoter lentiviruses have been used, as well as excisable, doxycycline inducible and constitutive lentivectors $^{[18,32,33]}$. 


\section{Table I Dedifferentiation methods}

\begin{tabular}{|c|c|c|c|c|}
\hline Method & Technique & Advantages & Disadvantages & Efficiencies \\
\hline $\begin{array}{l}\text { Nuclear } \\
\text { transfer }\end{array}$ & $\begin{array}{l}\text { A somatic cell nucleus is fusioned with a mature } \\
\text { enucleated oocyte }\end{array}$ & $\begin{array}{l}\text { hES cell lines can be established via } \\
\text { heterologous fusion. }\end{array}$ & $\begin{array}{l}\text { Epigenetic reprogramming outcome } \\
\text { is impossible to predict }\end{array}$ & - \\
\hline Cell extracts & $\begin{array}{l}\text { Differentiated cells are incubated with ES cells extracts in } \\
\text { order to drive them to express ES cells profiles. }\end{array}$ & $\begin{array}{l}\text { It allows biochemical and kinetic } \\
\text { analysis of reprogramming. } \\
\text { It may result useful for genetic } \\
\text { identification of reprogramming } \\
\text { factors. }\end{array}$ & \begin{tabular}{|c|} 
Difficult to conclude if the protein \\
expression profile of the target cell \\
corresponds to its own protein \\
production or if it is consequence of \\
the transient expression of the \\
protein molecules taken from the \\
extracts in which the cells are \\
growing.
\end{tabular} & - \\
\hline $\begin{array}{l}\text { Forced } \\
\text { expression of } \\
\text { defined } \\
\text { factors }\end{array}$ & $\begin{array}{l}\text { Transfection of embryonic cells with set combinations of } \\
\text { Oct4, Sox2, c-Myc, KIf4, Nanog, Stat3, Lin28, Esrrb, } \\
\text { SV40LT, UTF-1, p53 siRNA, hTERT, Wnt3a and Nr5a2. }\end{array}$ & $\begin{array}{c}\text { The most explored technique that } \\
\text { has given higher efficiencies. } \\
\text { Non-integration approaches may lead } \\
\text { to safe clinical applications. Used } \\
\text { with LMW increases efficiencies. }\end{array}$ & $\begin{array}{c}\text { Use of retrovirus and adenovirus can } \\
\text { cause reactivation of cancer genes } \\
\text { once they are fully integrated in the } \\
\text { host's genome. The dedifferentiation } \\
\text { protocols have not been streamlined } \\
\text { yet as techniques are not fully } \\
\text { optimized. }\end{array}$ & $\begin{array}{c}0.001 \text { to } 4.4 \% \text {, depending on the } \\
\text { cell line. The best efficiencies } \\
\text { are given by RNA transduction. } \\
\text { When OSKM+p53 siRNA+UTF-1 } \\
\text { are used efficiencies increase } \\
\text { up100X, compared with OSKM } \\
\text { alone. }\end{array}$ \\
\hline $\begin{array}{l}\text { Synthetic } \\
\text { molecules }\end{array}$ & $\begin{array}{l}\text { Low molecular weight (LMW) compounds may be used as } \\
\text { reprogramming reagents. Reversina has been able to } \\
\text { generate cells with osteogenic and adipogenic } \\
\text { differentiation capabilities from myoblasts. } \\
\text { Suberaylanide hidroxamic acid (SAHA), trichostatin A } \\
\text { (TSA), valproic acid (VPA), 5' azaC, RG108, BIX-01294, } \\
\text { A-83-01, BayK8644 and dexamethasone have also been } \\
\text { used. }\end{array}$ & $\begin{array}{l}\text { May be useful as a tool for controlling } \\
\text { stem cell fate and for further } \\
\text { understanding of developmental } \\
\text { processes. }\end{array}$ & $\begin{array}{c}\text { There is not a single compound with } \\
\text { ability to generate iPS cells. Only } \\
\text { cells with different differentiation } \\
\text { abilities from the original have been } \\
\text { generated. }\end{array}$ & $\begin{array}{c}\text { The use of certain LMW } \\
\text { compounds was able to increase } \\
2.6 \text { - } 100 \text { times the } \\
\text { reprogramming efficiency when } \\
\text { combined with forced expression } \\
\text { of defined factors. }\end{array}$ \\
\hline miRNA & $\begin{array}{l}\text { The objective of this method is to alter the cell protein } \\
\text { synthesis profile via microRNAs. }\end{array}$ & $\begin{array}{c}\text { When used with forced expression of } \\
\text { defined genes, Mir-290 can replace } \\
\text { c-Myc. }\end{array}$ & $\begin{array}{l}\text { It is not well understood yet as to } \\
\text { how transcription factors and } \\
\text { miRNAs interact. }\end{array}$ & - \\
\hline
\end{tabular}

Undoubtedly the work reported in 2006 by Takashi et al. who reprogrammed mouse somatic cells into iPS cells using OSKM was the watershed of pluripotent cells generation [17]. One year later, they repeated their success using human fibroblasts ${ }^{[34]}$.

Different groups are working on ways to reduce the quantity of genes involved in the dedifferentiation process; nevertheless as it reduces the cell to be transformed, this event needs to be on an earlier developmental stage ${ }^{[30,35-38]}$. The final objective remains; finding the minimum necessary genes that would be able to drive the somatic cell to the pluripotent stage.

So far, murine hepatic cells ${ }^{[17]}$, adult and embryonic fibroblasts (MEF) ${ }^{[28,34,37,39]}$ as well as human fibroblasts ${ }^{[13,}$ $23,30,31,33,37,38,40,41]$, keratinocytes ${ }^{[33,35]}$, lymphocytes ${ }^{[42]}$, hepatocytes ${ }^{[13]}$ adipose ${ }^{[43-45]}$, brain ${ }^{[46]}$ and spleen ${ }^{[28]}$ cells have been used to experiment. The best results have been obtained with adipose cells and keratinocytes, getting with the latter, dedifferentiation efficiencies up to $0.1 \%$, a value 100 times more efficient than and twice as fast as reprogramming of human fibroblasts, when reprograming with single DNA vectors ${ }^{[35]}$.

The use of single retroviral, adenoviral or lentiviral vectors is a topic of focus too. Sommer et al. ${ }^{[47]}$ developed a lentiviral cassette with the four transcription factors (OSKM), a combination of $2 \mathrm{~A}$ peptide and internal ribosome entry site (IRES) technology.
They reported reprogramming efficiencies ten times higher than those previously described, reaching up to $0.5 \%$. Experiments with polycistronic constructs and homologus recombination had also been done, reporting efficiencies five times higher than those with separated-gene vectors ${ }^{[41,48]}$. Their use of loxP sites represented the first steps toward non-integration methodologies; thus they virtually eliminated oncogenic risks due to transgene reactivation.

Kaji et al. ${ }^{[49]}$ were able to reprogram efficiently MEFs and human fibroblasts, with a single non-viral vector including $2 \mathrm{~A}$ peptide-linked reprogramming factors combined with a piggyBac (PB) transposon delivery system, obtaining dedifferentiation efficiencies up to $2.5 \%$. Woltjen et al. ${ }^{[50]}$ also worked with those cells delivering OSKM by PB transposition and doxycycline. As opposed to Cre-excisable transgenes, PBs do not leave a genomic scar because the transposon is precisely deleted without an integration site sequence modification after removal is done.

\section{Non integrative}

Four approaches directed to overcome integrative techniques disadvantages have been explored: integration-defective viral, episomal, RNA and protein deliveries ${ }^{[51,52]}$.

Integration-defective method uses replication-defective adenoviral or F-deficient Sendai viral vectors. The first ones 
using non-replicating ${ }^{\lfloor b s-b /\rfloor}$ or replicating ${ }^{[21]}$ episomal approaches do not guarantee plasmid-free integration iPS, as only 33 and $8 \%$ of total transduced cells showed no sign of plasmid integration respectively. Another major issue with this technique is the use of SV4OLT oncoprotein as reprogramming factor, when oriP/Epstein-Barr nuclear antigen-1 episomal vectors (oriP/EBNA1) are used in order to overcome episome dilution consequence of cell division ${ }^{[21]}$. An alternative approach proposed by Jia et al. is increased efficiency by reducing episome size by use of non-integrative minicircles, obtaining iPS cells in 14-16 days ${ }^{[57]}$.

In order to completely eliminate viral or plasmid vectors, Warren et al. proposed RNA conversion, their efficiency with fibroblasts reaching up to $4.4 \%{ }^{[58]}$, the highest reported so far. Nevertheless the gene amounts needed for transduction are so high that they might represent an oncogenic risk. The cells obtained by this procedure are known as piPS. In this approach, recombinant proteins fused with transduction mediating peptides have been delivered in the presence ${ }^{[51]}$ and absence of valproic acid (VPA) ${ }^{[52]}$, but the method kinetics are slow and its efficiencies are low. Additionally, protein production and purification is a complex process that does not certify experimental reproducibility.

\subsubsection{Synthetic molecules}

The identification of low molecular weight (LMW) compounds, which can function as reprogramming reagents, is one of the major chemistry-related stem cell culture research topics, as it can be a safe, rapid and efficient way for somatic cell reprogramming with in situ applications. The use of a small compound called reversina has shown the ability to induce cellular dedifferentiation in $\mathrm{C} 2 \mathrm{C} 12$ myoblasts, generating cells with osteogenic and adipogenic differentiation capabilities ${ }^{[7,9,59]}$.

In recent years, mainly DNA methyltransferase and histone deacetylase (HDAC) inhibitors have been used to improve reprogramming efficiency when forced expressions of defined genes or somatic cell nuclear transfer techniques are applied. The most common HDAC inhibitors are suberoylanide hidroxamic acid (SAHA), trichostatin A (TSA) and VPA. Even the most popular DNA methyltransferase inhibitor is 5' azaC, RG108 and BIX-01294 are being investigated as they give better efficiency yields ${ }^{[60,61]}$. Also the steroid glucocorticoid dexamethasone, the TGF- $\beta$ inhibitor A-83-01 [62] and the L-type calcium agonist BayK8644 ${ }^{[60]}$ have been studied.

Different experiments have been done with MEFs which when combined with forced expression of Oct4, Sox2, KIf4 and c-Myc genes, 5' azaC and dexamethasone increase by 10 -fold and 2.6-fold respectively, the reprogramming efficiency. On the other hand, when VPA is used, the efficiency reaches a 100-fold over the control experiment on a dose dependent manner. VPA may control a rate limiting step in reprogramming, but alone it is insufficient to reprogram MEFs ${ }^{[30]}$. When three genes are used, 5' azaC improves reprogramming three times, while VPA improves it up to fifty times. When knock-out (KO) is used, RG108 enhances efficiency up to nearly 30 times and BayK8644 up to 15 times.
Recently, Li et al. ${ }^{[36]}$ were able to derive iPS cells from mouse embryonic and adult fibroblasts in the presence of only Oct4 and a combination of synthetic molecules. LMW compounds may be useful for controlling stem cell fate and for further understanding of developmental processes ${ }^{[7]}$. The question remains open: is there going to be a day when reprogramming could be done by pure chemical methods? ${ }^{[9}$,

\subsection{4 $\operatorname{miRNA}$}

The objective of this method is to alter the cell protein synthesis profile ${ }^{[9]}$. With the discovery of microRNA (miRNA), a new perspective in the way dedifferentiation is done has been achieved. It is not well understood yet how transcription factors and miRNAs interact. It is still believed that miRNA maintains steady-state physiology of differentiated cells, rather than trigger cell differentiation. Altering its load, the cellular response to exogenic factors that reprogram gene expression may improve, making it more compatible with the acquisition of a pluripotent state ${ }^{99}$.

Experiments have been done using mir-302 miRNA, in Colo and PC3 human cancer cell lines. Once dedifferentiated, miRNA induced pluripotent stem cells (mirPS) were able to differentiate into neuron-, chondrocyte-, fibroblast- and spermatogonia-like primordial cells ${ }^{[63]}$

Mir-290 cluster has been evaluated in MEFs. Experiments show that this cluster enhances the efficiency of dedifferentiation when expression of OSK genes is forced. Maybe miRNA can replace c-Myc in promoting dedifferentiation of somatic cells. Small RNAs could replace additional factors, which may eventually substitute the use of introduced DNA elements ${ }^{[64]}$. It has been demonstrated that increased miRNA-145 expression inhibits hESC self-renewal, represses expression of pluripotency genes and induces lineage-restricted differentiation ${ }^{[65]}$.

\section{$1.2 \quad$ Future trends}

Many different approaches are being explored, but the optimal method has not been found. Undoubtedly, the main efforts are focused in faster, safer and more efficient processes.

The forced expression of defined genes is the most studied technology. The main research efforts are focused in nonintegration mechanisms and in optimizing the gene combination required for iPS generation ${ }^{[66]}$.

Even recombinant protein usage is safer but the results obtained so far are not encouraging, as the method is slow and inefficient ${ }^{[51,52]}$.

Synthetic molecules act as well proven efficiency optimizers but chemists and biologists should work together to generate or identify a group of LMW molecules that can act as transcription factor substitutes as well as protein extracts obtaining optimization, in order to generate gene usage free iPS cells.

The use of miRNA is still a promising alternative. When a more precise comprehension of this type of RNA and its role 
in dedifferentiation process is achieved, the non-integration problem could be solved by the application of this technique.

Efficiency and non-integration issues are addressed as major problems. iPS cell characteristics should not be underestimated as epigenetic remodeling, stability, transcriptional characteristics, genomic integrity and tumorigenic potential should be analyzed, so that it can be said that iPS resemble ES cells and the first can be used as substitutes of the later in cell therapy ${ }^{[67-69]}$.

\section{Conclusion}

Many problems remain to be solved in order to achieve clinical application level of this technology. The most encouraging method is the forced gene expression. The major part of the research efforts are focused in this topic. The main problem when viral vectors are used is that they are capable of activating oncogenic pathways, and nonintegrative methods are not able to give efficient results yet.

The search of economically and ethically feasible solutions for global biomedical problems related to tissue regeneration is the main concept that incites research groups' efforts all over the world.

Diverse techniques are being explored and encouraging results are being generated. Based on them, the investigations should be reoriented. Forced expression of defined genes and synthetic molecules are maybe the most potential methods, but it is necessary to get out the box and see the problem from a different point of view.

There is a lot of work pending; further investigation is needed in order to unravel the molecular and cellular mechanisms of stem cell pluripotency, as better understanding of the internal cell profile rearrangement may answer many unsolved questions and lead researchers to explore or not, paths that could improve iPS cells generation.

This technique enables the creation of patient specific stem cells lines to study different disease mechanisms; it would increase the efficiency in drug discovery; it is a valuable tool for toxicology testing providers and it may provide customized patient specific screening and tissue regeneration therapies both possible and economically feasible.

Scientists are in front of a very challenging and awaited therapeutic solution. Surely, all the summarized efforts will give a clinical application that will change the way medicine treats diseases.

\section{References}

1. Smith A. A glossary for stem-cell biology. Nature. 2006; 441(1060).

2. Pan GJ, Chang ZY, Schoeler HR, Pei D. Stem cell pluripotency and transcription factor Oct4. Cell Research. 2002;12(5-6):321-9.

3. Boiani M, Schöler HR. Regulatory networks in embryoderived pluripotent stem cells. Nat Rev Mol Cell Biol. 2005; 6(11):872-84.
4. Evans MJ, Kaufman MH. Establishment in culture of pluripotential cells from mouse embryos. Nature. 1981; 292(5819):154-6.

5. Ellis J, Baum C, Benvenisty N, Mostoslavsky G, Okano H, Stanford WL, Porteus M, Sadelain M. Benefits of utilizing gene-modified iPSCs for clinical applications. Cell Stem Cell. 2010; 7(4):429-30.

6. Inoue $\mathrm{H}$, Yamanaka $\mathrm{S}$. The use of induced pluripotent stem cells in drug development. Clinical Pharmacology and Therapeutics. 2011; 89(5):655-61.

7. Sartipy $P$, Strehl R, Björquist $P$, Hyllner J. Low molecular weight compounds for in vitro fate determination of human embryonic stem cells. Pharmacol Res.2008; 58(2):152-7.

8. Cai S, Fu Z, Sheng Z. Dedifferentiation: a new approach in stem cell research. Bioscience. 2007; 57(8):655-62.

9. Alberio R, Campbell KH, Johnson AD. Reprogramming somatic cells into stem cells. Reproduction. 2006; 132(5):709-20.

10. Morgan HD, Santos F, Green K, Dean W, Reik W. Epigenetic reprogramming in mammals. Hum Mol Genet. 2005; 14 Spec No 1:R47-58.

11. Freberg CT, Dahl JA, Timoskainen S, Collas P. Epigenetic reprogramming of OCT4 and NANOG regulatory regions by embryonal carcinoma cell extract. Mol Biol Cell. 2007 ; 18(5):1543-53.

12. Hochedlinger $\mathrm{K}$, Jaenisch $\mathrm{R}$. Nuclear reprogramming and pluripotency. Nature. 2006 ;441(7097):1061-7.

13. Taranger CK, Noer A, Sørensen AL, Håkelien AM, Boquest AC, Collas P. Induction of dedifferentiation, genomewide transcriptional programming, and epigeneticreprogramming by extracts of carcinoma and embryonic stem cells. Mol Biol Cell. 2005; 16(12):5719-35.

14. Hansis C, Barreto G, Maltry N, Niehrs C. Nuclear reprogramming of human somatic cells by xenopus egg extract requires BRG1. Curr Biol. 2004; 14(16):1475-80.

15. Bru T, Clarke C, McGrew MJ, Sang HM, Wilmut I, Blow JJ. Rapid induction for pluripotency genes after exposure of human somatic cells to mouse ES cell extracts. Exp Cell Res. 2008; 314(14):2634-42.

16. Cho HJ, Lee CS, Kwon YW, Paek JS, Lee SH, Hur J, Lee EJ, Roh TY, Chu IS, Leem SH, Kim Y, Kang HJ, Park YB, Kim HS. Induction of pluripotent stem cells from adult somatic cells by protein-based reprogramming without genetic manipulation. Blood. 2010; 116(3):386-95.

17. Takahashi K, Yamanaka S. Induction of pluripotent stem cells from mouse embryonic and adult fibroblast cultures by defined factors. Cell. 2006; 126(4):663-76

18. Yu J, Vodyanik MA, Smuga-Otto K, Antosiewicz-Bourget J, Frane JL, Tian S, Nie J, Jonsdottir GA, Ruotti V, Stewart R, Slukvin II, Thomson JA. Inducedpluripotent stem cell lines derived from human somatic cells. Science. 2007; 318(5858):1917-20.

19. Liao J, Wu Z, Wang Y, Cheng L, Cui C, Gao Y, Chen T, Rao L, Chen S, Jia N, Dai H, Xin S, Kang J, Pei G, Xiao L. Enhanced efficiency of generating induced pluripotent stem (iPS) cells from human somatic cells by a combination of six transcription factors. Cell Res. 2008; 18(5):600-3.

20. Feng $B$, Jiang J, Kraus $P, \mathrm{Ng} \mathrm{JH}$, Heng JC, Chan $Y S$, Yaw LP, Zhang W, Loh YH, Han J, Vega VB, CacheuxRataboul V, Lim B, Lufkin $\mathrm{T}, \mathrm{Ng} \mathrm{HH}$. Reprogramming of fibroblasts into induced pluripotent stem cells with orphan nuclear receptor Esrrb. Nat Cell Biol. 2009; 11(2):197-203.

21. Yu J, Hu K, Smuga-Otto K, Tian S, Stewart R, Slukvin II, Thomson JA. Human induced pluripotent stem cells free of vector and transgene sequences. Science. 2009; 324(5928):797-801.

22. Mali P, Ye Z, Hommond HH, Yu X, Lin J, Chen G, Zou J, Cheng $L$. Improved efficiency and pace of generating induced pluripotent stem cells from human adult and fetal fibroblasts. Stem Cells. 2008; 26(8):1998-2005. 
23. Park IH, Zhao $R$, West JA, Yabuuchi A, Huo $H$, Ince TA Lerou PH, Lensch MW, Daley GQ. Reprogramming of human somatic cells to pluripotency with defined factors. Nature. 2008; 451(7175):141-6.

24. Zhao $Y$, Yin $X$, Qin $H$, Zhu $F$, Liu $H$, Yang $W$, Zhang $Q$, Xiang $C$, Hou $P$, Song Z, Liu Y, Yong J, Zhang P, Cai J, Liu M, Li H, Li Y, Qu X, Cui K, Zhang W, Xiang T, Wu Y, Zhao Y, Liu C, Yu C, Yuan K, Lou J, Ding M, Deng H. Two supporting factors greatly improve the efficiency of human iPSC generation. Cell Stem Cell. $2008 ; 3(5): 475-9$

25. Pfannkuche K, Fatima A, Gupta MK, Dieterich R, Hescheler J. Initial colony morphology-based selection for iPS cells derived from adult fibroblasts is substantially improved by temporary UTF1-based selection. PLoS One. 2010 5(3):e9580.

26. Marson A, Foreman R, Chevalier B, Bilodeau S, Kahn M, Young $R$, et al. Wnt signaling promotes reprogramming of somatic cells to pluripotency. Cell Stem Cell. 2008; 3(2):1325.

27. Heng JC, Feng B, Han J, Jiang J, Kraus $\mathrm{P}, \mathrm{Ng} J \mathrm{H}$, Orlov $\mathrm{YL}$, Huss $\mathrm{M}$, Yang L, Lufkin T, Lim B, Ng HH. The nuclear receptor $\mathrm{Nr} 5 \mathrm{a} 2$ can replace Oct4 in the reprogramming of murine somatic cells to pluripotent cells. Cell Stem Cell. 2010; 6(2):167-74

28. Jiang $Y$, Jahagirdar $B N$, Reinhardt RL, Schwartz RE, Keene $C D$, Ortiz-Gonzalez $X R$, Reyes $M$, Lenvik $T$, Lund $T$, Blackstad M, Du J, Aldrich S, Lisberg A, Low WC, Largaespada DA, Verfaillie CM. Pluripotency of mesenchymal stem cells derived from adult marrow. Nature. 2002; 418(6893):41-9.

29. Zaehres H, Schöler HR. Induction of pluripotency: from mouse to human. Cell. $2007 ; 131(5): 834-5$.

30. Huangfu D, Osafune K, Maehr R, Guo W, Eijkelenboom A, Chen S, Muhlestein W, Melton DA. Induction of pluripotent stem cells from primary human fibroblasts with only Oct4 and Sox2. Nat Biotechnol. 2008; 26(11):1269-75.

31. Stadtfeld M, Nagaya M, Utikal J, Weir G, Hochedlinger K Induced pluripotent stem cells generated without viral integration. Science. 2008; 322(5903):945-9.

32. Blelloch R, Venere M, Yen J, Ramalho-Santos M.Generation of induced pluripotent stem cells in the absence of drug selection.Cell Stem Cell. 2007; 1(3):245-7.

33. Maherali N, Ahfeldt T, Rigamonti A, Utikal J, Cowan C, Hochedlinger K. A high-efficiency system for the generation and study of human induced pluripotent stem cells. Cell Stem Cell. 2008; 3(3):340-5.

34. Takahashi K, Tanabe K, Ohnuki M, Narita M, Ichisaka T, Tomoda K, Yamanaka S. Induction of pluripotent stem cells from adult human fibroblasts by defined factors. Cell. 2007; 131(5):861-72.

35. Aasen T, Raya A, Barrero MJ, Garreta E, Consiglio A, Gonzalez F, Vassena R, Bilić J, Pekarik V, Tiscornia G, Edel $\mathrm{M}$, Boué S, Izpisúa Belmonte JC. Efficient and rapid generation of induced pluripotent stem cells from human keratinocytes. Nat Biotechnol. 2008; 26(11):1276-84.

36. Li Y, Zhang Q, Yin X, Yang W, Du Y, Hou P, Ge J, Liu C, Zhang W, Zhang $X$, Wu Y, Li H, Liu K, Wu C, Song Z, Zhao $Y$, Shi $Y$, Deng H. Generation of iPSCs from mouse fibroblasts with a single gene, Oct4, and small molecules. Cell Res. 2011; 21(1):196-204

37. Nakagawa $M$, Koyanagi $M$, Tanabe $K$, Takahashi $K$ Ichisaka T, Aoi T, Okita K, Mochiduki Y, Takizawa N Yamanaka S. Generation of induced pluripotent stem cells without Myc from mouse and human fibroblasts. Nat Biotechnol. 2008; 26(1):101-6.

38. Wernig M, Meissner A, Foreman R, Brambrink T, Ku M, Hochedlinger $\mathrm{K}$, Bernstein $\mathrm{BE}$, Jaenisch $\mathrm{R}$. In vitro reprogramming of fibroblasts into a pluripotent ES-cell-like state. Nature. 2007; 448(7151):318-24.

39. French AJ, Adams CA, Anderson LS, Kitchen JR, Hughes MR, Wood SH. Development of human cloned blastocysts following somatic cell nuclear transfer with adult fibroblasts. Stem Cells. 2008; 26(2):485-93.
40. Lowry WE, Richter L, Yachechko R, Pyle A, Tchieu J, Sridharan R, et al. Generation of human induced pluripotent stem cells from dermal fibroblasts. PNAS. 2008;105(8):2883-8.

41. Chang CW, Lai YS, Pawlik KM, Liu K, Sun CW, Li C, Schoeb TR, Townes TM. Polycistronic lentiviral vector for "hit and run" reprogramming of adult skin fibroblasts to induced pluripotent stem cells. Stem Cells. 2009; 27(5):1042-9.

42. Brown ME, Rondon E, Rajesh D, Mack A, Lewis R, Feng $X$, Zitur LJ, Learish RD, Nuwaysir EF. Derivation of induced pluripotent stem cells from human peripheral blood T lymphocytes. PLoS One. 2010; 5(6):e11373.

43. Jia F, Wilson KD, Sun N, Gupta DM, Huang M, Li Z, Panetta NJ, Chen ZY, Robbins RC, Kay MA, Longaker MT, Wu JC. A nonviral minicircle vector for deriving human iPS cells. Nat Methods. 2010; 7(3):197-9.

44. Sugii S, Kida Y, Berggren WT, Evans RM. Feederdependent and feeder-independent iPS cell derivation from human and mouse adipose stem cells.Nat Protoc. $2011 ; 6(3): 346-58$

45. Sun N, Panetta NJ, Gupta DM, Wilson KD, Lee A, Jia F $\mathrm{Hu}$ S, Cherry AM, Robbins RC, Longaker MT, Wu JC. Feeder-free derivation of induced pluripotent stem cells from adult human adipose stem cells. Proc Natl Acad Sci U S A. 2009; 106(37):15720-5.

46. Kim JB, Zaehres H, Wu G, Gentile L, Ko K, Sebastiano V, Araúzo-Bravo MJ, Ruau D, Han DW, Zenke M, Schöler HR. Pluripotent stem cells induced from adult neural stem cells by reprogramming with two factors. Nature. 2008; 454(7204):646-50

47. Sommer CA, Stadtfeld M, Murphy GJ, Hochedlinger K, Kotton DN, Mostoslavsky G. Induced pluripotent stem cell generation using a single lentiviral stem cell cassette. Stem Cells. 2009; 27(3):543-9.

48. Carey BW, Markoulaki S, Beard C, Hanna J, Jaenisch R. Single-gene transgenic mouse strains for reprogramming adult somatic cells. Nat Methods. 2010; 7(1):56-9.

49. Kaji K, Norrby K, Paca A, Mileikovsky M, Mohseni P, Woltjen K. Virus-free induction of pluripotency and subsequent excision of reprogramming factors. Nature. 2009; 458(7239):771-5.

50. Woltjen K, Michael IP, Mohseni P, Desai R, Mileikovsky $M$, Hämäläinen $R$, Cowling $R$, Wang $W$, Liu $P$, Gertsenstein M, Kaji K, Sung HK, Nagy A. piggyBac transposition reprograms fibroblasts to induced pluripotent stem cells. Nature. 2009; 458(7239):766-70.

51. Zhou H, Wu S, Joo JY, Zhu S, Han DW, Lin T, Trauger S, Bien G, Yao S, Zhu Y, Siuzdak G, Schöler HR, Duan L, Ding S. Generation of induced pluripotent stem cells using recombinant proteins. Cell Stem Cell. 2009; 4(5):381-4.

52. Kim D, Kim CH, Moon Jl, Chung YG, Chang MY, Han BS, Ko S, Yang E, Cha KY, Lanza R, Kim KS. Generation of human induced pluripotent stem cells by direct delivery of reprogramming proteins. Cell Stem Cell. 2009; 4(6):472-6.

53. Zhou W, Freed CR. Adenoviral gene delivery can reprogram human fibroblasts to induced pluripotent stem cells. Stem Cells. 2009; 27(11):2667-74.

54. Fusaki N, Ban H, Nishiyama A, Saeki K, Hasegawa M. Efficient induction of transgene-free human pluripotent stem cells using a vector based on Sendai virus, an RNA virus that does not integrate into the host genome. Proc Jpn Acad Ser B Phys Biol Sci. 2009; 85(8):348-62.

55. Okita K, Nakagawa M, Hyenjong H, Ichisaka T, Yamanaka $\mathrm{S}$. Generation of mouse induced pluripotent stem cells without viral vectors. Science. 2008; 322(5903):949-53.

56. Gonzalez F, Barragan Monasterio M, Tiscornia G, Montserrat Pulido N, Vassena R, Batlle Morera L, Rodriguez Piza I, Izpisua Belmonte JC. Generation of mouse-induced pluripotent stem cells by transient expression of a single nonviral polycistronic vector. Proc Natl Acad Sci U S A. 2009; 106(22):8918-22. 
57. Jia F, Wilson KD, Sun N, Gupta DM, Huang M, Li Z, Panetta NJ, Chen ZY, Robbins RC, Kay MA, Longaker MT, Wu JC. A nonviral minicircle vector for deriving human iPS cells. Nat Methods. 2010; 7(3):197-9.

58. Warren L, Manos PD, Ahfeldt T, Loh YH, Li H, Lau F, Ebina W, Mandal PK, Smith ZD, Meissner A, Daley GQ, Brack AS, Collins JJ, Cowan C, Schlaeger TM, Rossi DJ. Highly efficient reprogramming to pluripotency and directed differentiation of human cells with synthetic modified mRNA. Cell Stem Cell. 2010; 7(5):618-30.

59. Chen $S$, Zhang $Q$, Wu $X$, Schultz PG, Ding $S$. Dedifferentiation of lineage-committed cells by a small molecule. J Am Chem Soc. 2004; 126(2):410-1.

60. Shi Y, Desponts C, Do JT, Hahm HS, Schöler HR, Ding S. Induction of pluripotent stem cells from mouse embryonic fibroblasts by Oct4 and Klf4 with small-molecule compounds. Cell Stem Cell. 2008; 3(5):568-74.

61. Shi Y, Do JT, Desponts C, Hahm HS, Schöler HR, Ding S. A combined chemical and genetic approach for the generation of induced pluripotent stem cells. Cell Stem Cell. 2008; 2(6):525-8.

62. Li W, Wei W, Zhu S, Zhu J, Shi Y, Lin T, Hao E, Hayek A, Deng $H$, Ding $S$. Generation of rat and human induced pluripotent stem cells by combining genetic reprogramming and chemical inhibitors. Cell Stem Cell. 2009; 4(1):16-9.

63. Lin SL, Chang DC, Chang-Lin S, Lin CH, Wu DT, Chen DT, Ying SY. Mir-302 reprograms human skin cancer cells into a pluripotent ES-cell-like state. RNA. 2008; 14(10):2115-24.

Potential Conflict of Interests:

None

Abbreviations used in the article:

ES: $\quad$ Embryonic stem

hES: Human embryonic stem

iPS: Induced pluripotent stem

KO: Knock-out

MEF: Mouse embryonic fibroblasts

MESC: Mouse embryonic stem cells

SAHA: Suberoylanide hidroxamic acid

TSA: Trichostatin A

VPA: Valproic acid
64. Judson RL, Babiarz JE, Venere M, Blelloch R. Embryonic stem cell-specific microRNAs promote induced pluripotency. Nat Biotechnol. 2009; 27(5):459-61.

65. Xu N, Papagiannakopoulos T, Pan G, Thomson JA, Kosik KS. MicroRNA-145 regulates OCT4, SOX2, and KLF4 and represses pluripotency in human embryonic stem cells. Cell. 2009; 137(4):647-58.

66. Papapetrou EP, Tomishima MJ, Chambers SM, Mica $Y$, Reed E, Menon J, Tabar V, Mo Q, Studer L, Sadelain M. Stoichiometric and temporal requirements of Oct4, Sox2, KIf4, and c-Myc expression for efficient human iPSC induction and differentiation. Proc Natl Acad Sci U S A. 2009; 106(31):12759-64.

67. Boué S, Paramonov I, Barrero MJ, Izpisúa Belmonte JC. Analysis of human and mouse reprogramming of somatic cells to induced pluripotent stem cells. What is in the plate? PLoS One. 2010; 5(9).

68. Maherali N, Sridharan R, Xie W, Utikal J, Eminli S, Arnold K, Stadtfeld M, Yachechko R, Tchieu J, Jaenisch R, Plath K, Hochedlinger K. Directly reprogrammed fibroblasts show global epigenetic remodeling and widespread tissue contribution. Cell Stem Cell. 2007; 1(1):55-70.

69. Mikkelsen TS, Ku M, Jaffe DB, Issac B, Lieberman $E$, Giannoukos G, Alvarez P, Brockman W, Kim TK, Koche RP, Lee W, Mendenhall E, O'Donovan A, Presser A, Russ C, Xie X, Meissner A, Wernig M, Jaenisch R, Nusbaum C, Lander ES, Bernstein BE. Genome-wide maps of chromatin state in pluripotent and lineage-committed cells. Nature. 2007; 448(7153):553-60.

\section{Correspondence to be addressed to:}

Jorge Eugenio Moreno Cuevas, 3000 Ignacio Morones Prieto Av. 3rd. floor, Zip Code 64710, Monterrey, Nuevo León, México. +52 (81) 88882141 Fax. (81) 8888 2148; jemoreno@itesm.mx 